\title{
The impact of Romanisation on Hippophagy and Cynophagy: a long-term perspective from Lyon, France
}

\begin{abstract}
Lyon (Rhône, France) has been permanently occupied since the late Neolithic (c.2000 B.C.) and, up until the end of second Iron Age (mid- ${ }^{{ }^{s t}} \mathrm{c}$. B.C.) at least, the site has regularly produced zoo archaeological evidence for dog and equid consumption. After the establishment of the Roman colony of Lugdunum, however such evidence disappears from faunal assemblages, a time when new phenomena such as dog burial and horse knackery emerges, particularly in suburban areas, only for it to reappear once more during the $2^{\text {nd }} \mathrm{c}$. A.D. This paper traces the changes in human exploitation of horses and dogs during the 1st millennium A.D. and focuses, in particular, on the impact of Roman cultural attitudes towards these species.
\end{abstract}

Keywords: Romanisation; Hippophagy; Cynophagy; France; Craft working; Iron age; Sheep and goats
Volume 2 Issue 2 - 2017

\section{Thierry Argant}

Laboratoire Archéométrie et Archéologie, France

Correspondence: Thierry Argant, Laboratoire Archéométrie et Archéologie, France, Tel 0667934848 ,

Email thierry.argant@eveha.fr

Received: June 20, 2017| Published: November 22, 2017

\section{Introduction}

Lyon (Rhône, France) has been permanently occupied since the late Neolithic (c. 2000 B.C.) and, up until the end of second Iron Age (mid1st c. B.C.) at least, the site has regularly produced zoo archaeological evidence for dog and equid consumption. After the establishment of the Roman colony of Lugdunum, however such evidence disappears from faunal assemblages, a time when new phenomena such as dog burial and horse knackery emerges, particularly in suburban areas, only for it to reappear once more during the 2 nd c. A.D. This paper traces the changes in human exploitation of horses and dogs during the 1st millennium A.D. and focuses, in particular, on the impact of Roman cultural attitudes towards these species.

\section{Historical context}

The city of Lyon is located in south-eastern France at the confluence of the River Saône, connecting from the north and the Rhône, flowing from the Alps, which together run south to the Mediterranean (Figure 1). The earliest evidence for settlement has been identified on the alluvial plain of Vaise in the northwest of the city and on the hills surrounding the Rhône in the east (Corbas, Vénissieux and Meyzieu). Since the middle of the 1980s, the development of rescue archaeology has allowed the identification of about thirty sites dating from the Hallstatt D2-D3 and La Tène Al periods (5th c. B.C.) and these are distributed over $c .150$ ha of the plain of Vaise. ${ }^{1}$ This occupation appears to have been extensive and unenclosed, with denser concentrations of structures found in the southern part of the plain (Figure 2). It is also marked by imported Mediterranean pottery associated with wine consumption. Both structures and finds provide evidence for agriculture and stock-raising alongside specialized craftworking, including iron and copper-alloy working, horn-working and textile production (Table 1).

At the end of the second Iron Age, in the middle of the 2nd c. B.C., Vaise remained an important meeting place with large ditches in which waste from feasts has been found discarded and these appear to correspond to a large, enclosed, high-status settlement. ${ }^{2}$ In 43 B.C., the
Senator and Consul, Munatius Plancus, established the Colonia Copia Felix Munatia Lugdunum with the status of Roman Colony of Right (optimo iure) on the summit of the hill of Fourvière. This represented the beginning of an era of prosperity which lasted about two centuries. The city rapidly expanded from the hillside onto the Presqu'île and in 12 B.C., became the provincial capital of the Three Gauls. Thereafter, Christianity gradually became more influential after it was introduced to Lugdunum by large numbers of Greek settlers from Asia Minor. In AD 177, the martyrdom of the Christians of Lyon took place, a point which marked the beginning of a period of decline for the city and by the end of the 3rd c. AD it had lost its status as provincial capital to Treves. The church recovered quickly, however and by the 5th c. A.D. the first cathedral was established in the city whilst the Burgondes occupied the region.

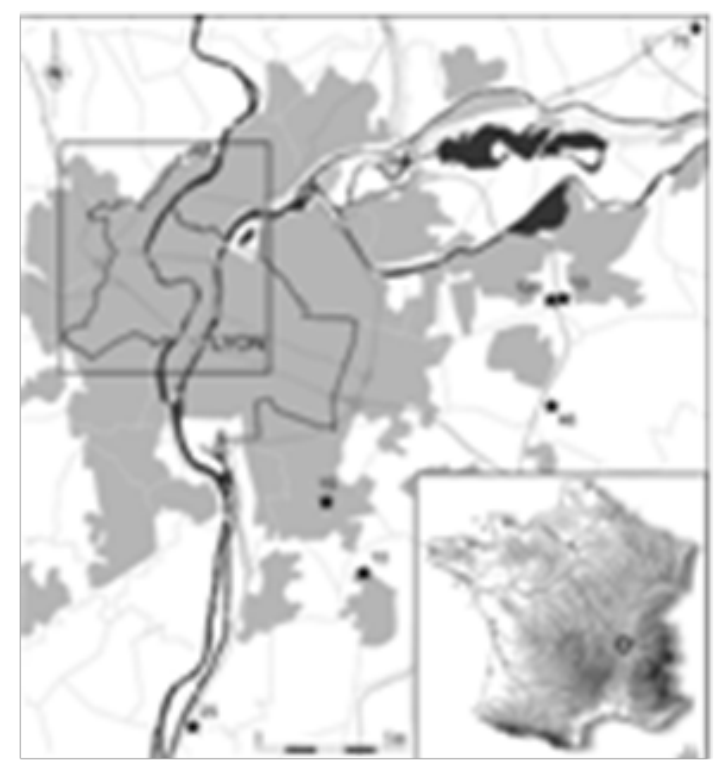

Figure I Location map of Lyon and surroundings with location of suburban sites. 
Table I Location of sites from Late Neolithic to Second Iron Age

\begin{tabular}{|c|c|c|c|c|c|c|c|c|c|c|c|c|}
\hline \multirow[b]{2}{*}{$\mathbf{N}^{\circ}$} & \multirow[b]{2}{*}{ Site } & \multicolumn{5}{|l|}{ Equids } & \multicolumn{4}{|l|}{ Dogs } & \multirow[b]{2}{*}{ Remarks } & \multirow[b]{2}{*}{ Source } \\
\hline & & $\begin{array}{l}\text { Total } \\
\text { NISP }\end{array}$ & NISP & Consumption & Craftwork & $\begin{array}{l}\text { Burial/ } \\
\text { Knackery }\end{array}$ & NISP & Consumption & Craftwork & $\begin{array}{l}\text { Burial/ } \\
\text { Knackery }\end{array}$ & & \\
\hline
\end{tabular}

Late Neolithic

\begin{tabular}{|c|c|c|c|c|c|c|c|c|c|c|c|}
\hline I & $\begin{array}{l}\text { II-13 rue } \\
\text { Roquette }\end{array}$ & 5 & 0 & - & - & - & 0 & - & - & - & Argant [18] \\
\hline 2 & BPNL & 96 & 0 & - & - & - & 0 & - & - & - & Forest [19] \\
\hline 3 & $\begin{array}{l}\text { Station métro } \\
\text { GDL }\end{array}$ & 14 & 0 & - & - & - & 0 & - & - & - & Méniel [20] \\
\hline
\end{tabular}

\section{Early Bronze Age}

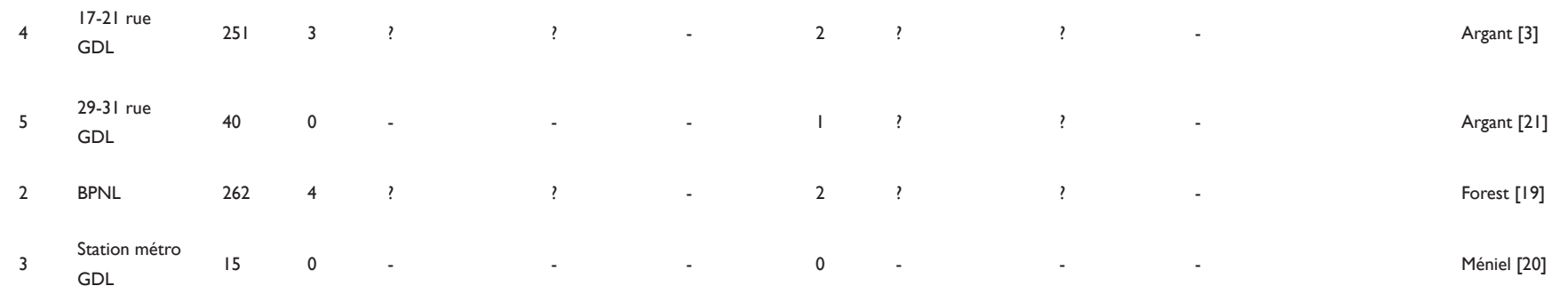

\section{Late Bronze Age}

\begin{tabular}{|c|c|c|c|c|c|c|c|c|c|c|c|c|}
\hline 5 & $\begin{array}{l}29-31 \text { rue } \\
\text { GDL }\end{array}$ & 12 & 0 & - & - & - & 1 & ? & ? & - & & Argant [2I] \\
\hline 2 & BPNL & 639 & 0 & - & - & - & 22 & ? & ? & - & & Forest [19] \\
\hline 10 & $\begin{array}{l}\text { Corbas - } \\
\text { Grand Champ }\end{array}$ & 66 & 0 & - & - & - & 0 & - & - & - & & Argant [3] \\
\hline 10 & $\begin{array}{l}\text { Corbas - } \\
\text { Grand Champ }\end{array}$ & 17 & 0 & - & - & - & 0 & - & - & - & & Argant [3] \\
\hline 12 & $\begin{array}{l}\text { Hôpital de } \\
\text { l'Antiquaille }\end{array}$ & 5 & 0 & - & - & - & 1 & + & - & - & radius & Argant [22] \\
\hline 13 & $\begin{array}{l}\text { Meyzieu - Les } \\
\text { Hernières }\end{array}$ & 129 & 0 & - & - & - & 1 & ? & ? & - & $\begin{array}{l}3 \text { month } \\
\text { puppy }\end{array}$ & Forest [23] \\
\hline 3 & $\begin{array}{l}\text { Station métro } \\
\text { GDL }\end{array}$ & 71 & 0 & - & - & - & 0 & - & - & - & & Méniel [20] \\
\hline 15 & Vénissieux & 100 & 2 & ? & ? & - & 2 & ? & ? & - & & Forest [24] \\
\hline
\end{tabular}

First Iron Age

\begin{tabular}{|c|c|c|c|c|c|c|c|c|c|c|c|c|}
\hline I & $\begin{array}{l}\text { II-13 rue } \\
\text { Roquette }\end{array}$ & 353 & 1 & ? & - & - & 4 & + & - & - & $\begin{array}{l}\text { clear } \\
\text { cutmarks on } \\
\text { dog }\end{array}$ & Argant [18] \\
\hline 17 & $\begin{array}{l}\text { 14, rue des } \\
\text { Tuileries }\end{array}$ & 731 & 0 & - & - & - & 6 & $?$ & - & c & $\begin{array}{l}\text { puppy and } \\
\text { old dog }\end{array}$ & Argant [25] \\
\hline 18 & $\begin{array}{l}\text { 4-6 rue du } \\
\text { Mont d'Or }\end{array}$ & 500 & 1 & ? & - & - & 0 & - & - & - & $\begin{array}{l}\text { not studied } \\
\text { yet! }\end{array}$ & unpublished \\
\hline 2 & BPNL & 158 & 2 & + & - & - & 0 & + & - & - & & Forest [19] \\
\hline
\end{tabular}


Table Continued....

\begin{tabular}{|c|c|c|c|c|c|c|c|c|c|c|c|c|}
\hline \multirow[b]{2}{*}{$\mathbf{N}^{\circ}$} & \multirow[b]{2}{*}{ Site } & \multicolumn{5}{|c|}{ Equids } & \multicolumn{4}{|l|}{ Dogs } & \multirow[b]{2}{*}{ Remarks } & \multirow[b]{2}{*}{ Source } \\
\hline & & $\begin{array}{l}\text { Total } \\
\text { NISP }\end{array}$ & NISP & Consumption & Craftwork & $\begin{array}{l}\text { Burial/ } \\
\text { Knackery }\end{array}$ & NISP & Consumption & Craftwork & $\begin{array}{l}\text { Burial/ } \\
\text { Knackery }\end{array}$ & & \\
\hline 20 & Horand 2 & 540 & 5 & + & - & - & 11 & + & - & - & & Argant [7] \\
\hline 20 & Horand 3 & 125 & 1 & + & - & - & 1 & + & - & - & & Argant [7] \\
\hline 20 & Horand 4 & 239 & 2 & + & - & - & 0 & + & - & - & & Argant [7] \\
\hline 24 & $\begin{array}{l}10, \text { rue } \\
\text { Marietton }\end{array}$ & 522 & 2 & + & - & - & 3 & + & - & - & & Argant [7] \\
\hline 25 & $\begin{array}{l}\text { Sérézin du } \\
\text { Rhône }\end{array}$ & 146 & 0 & - & - & - & 0 & - & - & - & & Poulain [26] \\
\hline 26 & $\begin{array}{l}65, \text { rue du } \\
\text { Souvenir }\end{array}$ & 193 & 1 & + & - & - & 1 & + & - & - & & Argant [7] \\
\hline 3 & $\begin{array}{l}\text { Station métro } \\
\text { GDL }\end{array}$ & 1083 & 15 & + & - & - & 8 & + & - & - & & Méniel [20] \\
\hline 15 & Vénissieux & 231 & 0 & - & - & - & 2 & $?$ & $?$ & $?$ & & Forest [24] \\
\hline 27 & $\begin{array}{l}\text { Rue Berthet/ } \\
\text { Cottin }\end{array}$ & 692 & 1 & $?$ & - & - & 5 & $?$ & + & - & $\begin{array}{l}\text { skinning on } \\
\text { dog }\end{array}$ & Lalaï [27] \\
\hline \multicolumn{13}{|c|}{ Second Iron Age } \\
\hline 24 & $\begin{array}{l}10, \text { rue } \\
\text { Marietton }\end{array}$ & 206 & 17 & $?$ & $?$ & $?$ & 0 & - & - & - & in a ditch & Argant [7] \\
\hline 18 & $\begin{array}{l}\text { 4-6 rue du } \\
\text { Mont d'Or }\end{array}$ & 500 & 1 & + & - & - & 1 & + & - & - & $\begin{array}{l}\text { not studied } \\
\text { yet, big dog }\end{array}$ & unpublished \\
\hline 31 & $\begin{array}{l}\text { Chais } \\
\text { Beaucairois }\end{array}$ & 3000 & 3 & - & - & + & 3 & + & - & + & $\begin{array}{l}\text { in tombs: } \\
\text { offering food } \\
\text { and sacrified } \\
\text { individuals }\end{array}$ & Argant [10] \\
\hline & Clos des & & & & & & & & & & & \\
\hline 32 & $\begin{array}{l}\text { Frères } \\
\text { Maristes }\end{array}$ & 6 & 1 & $?$ & - & - & 1 & $?$ & - & - & & Argant [14] \\
\hline 33 & $\begin{array}{l}\text { Hôpital Sainte- } \\
\text { Croix }\end{array}$ & 502 & 2 & $?$ & $?$ & $?$ & 15 & $?$ & $?$ & $?$ & & Krauz [8] \\
\hline 34 & Îlot Cordier & 687 & 108 & + & - & - & 6 & $?$ & - & $?$ & in a ditch & Jacquet [9] \\
\hline 35 & $\begin{array}{l}\text { Quartier } \\
\text { Saint-Vincent }\end{array}$ & 478 & 1 & $\mathrm{i}$ & - & - & 8 & + & - & - & $\begin{array}{l}\text { young equids } \\
\text { and dogs }\end{array}$ & Argant [7] \\
\hline 26 & $\begin{array}{l}\text { Rue du } \\
\text { Souvenir }\end{array}$ & 1347 & 51 & $?$ & $?$ & $?$ & 4 & $?$ & $?$ & $?$ & & Forest [28] \\
\hline 15 & Vénissieux & 24 & 0 & - & - & - & 2 & + & - & - & $\begin{array}{l}\text { cutmarks on } \\
\text { coxal bone }\end{array}$ & Forest [24] \\
\hline 38 & Verbe Incarné & 2624 & 20 & ? & ? & ? & 1 & ? & ? & ? & in a ditch & Goudineau [29] \\
\hline
\end{tabular}




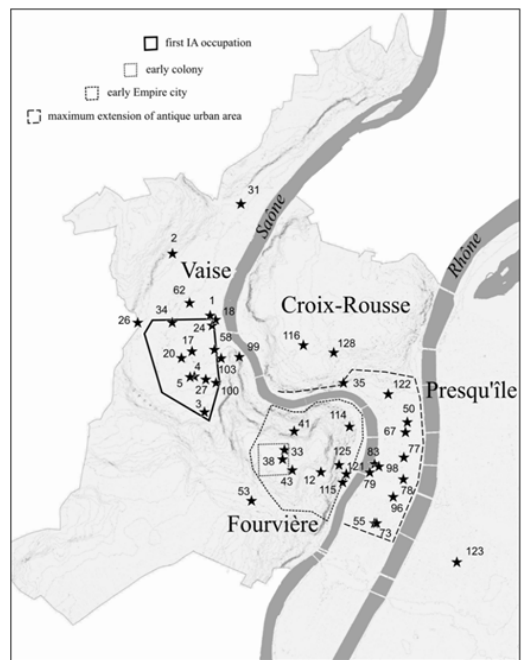

Figure 2 Map of the city (Service Archéologique de la Ville de Lyon), with the schematic area of the first Iron Age occupation (based on Carrara 2009), location and extension of Lugdunum from the rise of the colony to its maximum development (based on Le Mer and Chomer 2007) and location of sites mentioned in Table I.

\section{Meat-based diet}

To a large extent, cattle (Bos taurus) bones dominate many assemblages from Lyon dating between the late Neolithic and the end of first Iron Age. ${ }^{3}$ This pattern, particularly during first Iron Age, is quite similar to that recorded for the Saône valley, an area with similar geographical characteristics, while in south-eastern France, with its drier landscape, sheep/goat (Caprinae) remains are more common. ${ }^{4}$ By the end of second Iron Age in Lyon, pig (Suss domesticus) bones become more common (Figure 3). At the same time, red deer (Cervus elaphus) remains become less frequently identified than brown hare (Lepus europaeus), a change which appears to mirror a decline in the forest in the vicinity, as is shown by pollen analysis. ${ }^{5}$ At the beginning of the Roman period, pig remains continue to dominate many assemblages, though cattle become increasingly important again over time, a trend which correlates with the establishment of slaughterhouses and butcheries in the Roman town. ${ }^{3}$ For example, the site of Tramassac Street at the southern gate of the late Roman town revealed a striking example of one of these establishments, producing quantities of processed cattle remains. ${ }^{6}$ Outside the town limits, sheep/ goat bones are more commonly recovered, together with pigs, whilst cattle remains are less frequently identified and later, during the Early Middle Ages, sheep/goats continue to dominate (Table 2) (Table 3).

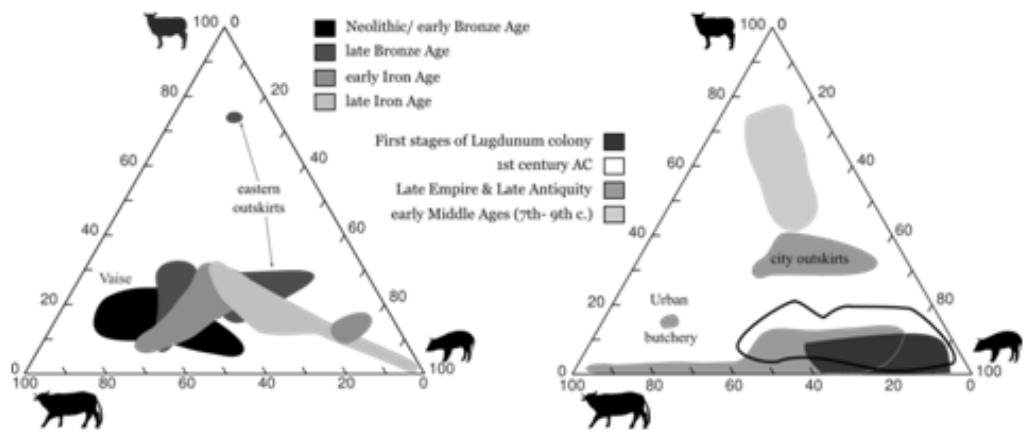

Figure 3 Tripolar plot of relative abundance inside domestic triad, from the Neolithic to the Early Middle Ages in Lyon.

Table 2 Location of sites in Early empire-augustean

\begin{tabular}{|c|c|c|c|c|c|c|c|c|c|c|c|c|}
\hline $\mathbf{N}^{\circ}$ & Site & & Equids & & & & Dogs & & & & Remarks & Source \\
\hline \multicolumn{13}{|c|}{ Early empire-augustean } \\
\hline I & $\begin{array}{l}\text { II-I3 rue } \\
\text { Roquette }\end{array}$ & 109 & 3 & - & - & $?$ & 0 & - & - & - & & Argant 18 \\
\hline 18 & $\begin{array}{l}4-6 \text { rue du Mont } \\
\text { d'Or }\end{array}$ & 218 & 0 & - & - & - & 0 & - & - & - & & Argant30 \\
\hline 32 & $\begin{array}{l}\text { Clos des Frères } \\
\text { Maristes }\end{array}$ & 40 & 0 & - & - & - & 0 & - & - & - & & Argant 18 \\
\hline 32 & $\begin{array}{l}\text { Clos des Frères } \\
\text { Maristes }\end{array}$ & 4 & 0 & - & - & - & 0 & - & - & - & & Argant 18 \\
\hline 43 & Cybèle - DI & 3587 & 0 & - & - & - & 31 & ? & $?$ & + & & Forest3I \\
\hline 43 & Cybèle - F2 & 640 & 0 & - & - & - & 0 & - & - & - & & Forest32 \\
\hline 43 & Cybèle - F2 & 647 & 0 & - & - & - & 1 & ? & - & ? & gracil tibia's diaphysis : might be fox & Forest32 \\
\hline 43 & Cybèle - BI4 & 3185 & 0 & - & - & - & 30 & $?$ & + & $?$ & $\begin{array}{l}3 \text { individual, healed fracture, cutmark on } \\
\text { femur, puppy }\end{array}$ & Argant3 \\
\hline 46 & Genas & 71 & I & ? & - & - & I & ? & - & - & beheaded horse, old dog & Argant33 \\
\hline
\end{tabular}


Table Continued...

\begin{tabular}{|c|c|c|c|c|c|c|c|c|c|c|c|}
\hline $\mathbf{N}^{\circ}$ & Site & & Equids & & & & Dogs & & & Remarks & Source \\
\hline \multicolumn{12}{|c|}{ Early empire-augustean } \\
\hline 47 & $\begin{array}{l}\text { Hôpital de } \\
\text { Fourvière }\end{array}$ & 41 & 0 & - & - & - & 0 & $-\quad-$ & - & & Argant34 \\
\hline 12 & $\begin{array}{l}\text { Hôpital de } \\
\text { l'Antiquaille }\end{array}$ & 95 & 0 & - & - & - & 0 & $-\quad-$ & - & & Argant22 \\
\hline 50 & Place de la Bourse & III & 0 & - & - & - & 0 & $-\quad-$ & - & & Forest 32 \\
\hline \multicolumn{12}{|c|}{ Early empire- Ist .AD } \\
\hline I & $\begin{array}{l}\text { II-I3 rue } \\
\text { Roquette }\end{array}$ & 113 & 5 & ? & - & - & 0 & - - & - & Suspicious marks & Argant 18 \\
\hline I & $\begin{array}{l}\text { II-I3 rue } \\
\text { Roquette }\end{array}$ & 60 & 5 & ? & - & + & I & ? - & - & Equids in well & Argant 18 \\
\hline 53 & $\begin{array}{l}\text { |9-2I rue Fossés } \\
\text { de Trion }\end{array}$ & 16 & 0 & - & - & - & 0 & - - & - & & Lalaï27 \\
\hline 54 & $\begin{array}{l}27 \text { rue Auguste } \\
\text { Comte }\end{array}$ & 45 & 0 & - & - & - & 0 & $-\quad-$ & - & & Argant35 \\
\hline 54 & $\begin{array}{l}27 \text { rue Auguste } \\
\text { Comte }\end{array}$ & 308 & 0 & - & - & - & 0 & $-\quad-$ & - & & Argant35 \\
\hline 54 & $\begin{array}{l}27 \text { rue Auguste } \\
\text { Comte }\end{array}$ & 107 & 0 & - & - & - & 10 & $-\quad-$ & + & Young dog in well & Argant35 \\
\hline 54 & $\begin{array}{l}27 \text { rue Auguste } \\
\text { Comte }\end{array}$ & 52 & I & ? & - & - & 0 & $-\quad-$ & - & 3rd phalanx & Argant35 \\
\hline 58 & 4 rue Saint-Didier & 208 & 17 & - & - & + & 8 & $-\quad-$ & + & Pathology & Argant36 \\
\hline 58 & 4 rue Saint-Didier & 106 & 19 & - & - & + & 36 & $-\quad-$ & + & Dwarf hound (type Ib) & Argant36 \\
\hline 18 & $\begin{array}{l}\text { 4-6 rue du Mont } \\
\text { d'Or }\end{array}$ & 221 & 0 & - & - & - & 0 & $-\quad-$ & - & & Argant30 \\
\hline 2 & BPNL & 589 & 90 & ? & ? & $?$ & 22 & ? ? & ? & & Forest 19 \\
\hline 62 & Clos des Arts & 274 & 53 & - & - & + & 0 & $-\quad-$ & - & Funerary context & $\begin{array}{l}\text { Schmitt et } \\
\text { al. } 37\end{array}$ \\
\hline 32 & $\begin{array}{l}\text { Clos des Frères } \\
\text { Maristes }\end{array}$ & 167 & 0 & - & - & - & 0 & $-\quad-$ & - & & Argant 14 \\
\hline 32 & $\begin{array}{l}\text { Clos des Frères } \\
\text { Maristes }\end{array}$ & 29 & 0 & - & - & - & 0 & - - & - & & Argantl4 \\
\hline 32 & $\begin{array}{l}\text { Clos des Frères } \\
\text { Maristes }\end{array}$ & 57 & 0 & - & - & - & 0 & $-\quad-$ & - & & Argant 14 \\
\hline 43 & Cybèle - DI & 2137 & 0 & - & - & - & I & $-\quad-$ & + & Medora & Forest3I \\
\hline 67 & Grand Bazar & 300 & I & - & - & - & 0 & $-\quad-$ & - & Mandible in pit & Lalaï27 \\
\hline 47 & $\begin{array}{l}\text { Hôpital de } \\
\text { Fourvière }\end{array}$ & 354 & 0 & - & - & - & 0 & - - & - & & Argant34 \\
\hline 47 & $\begin{array}{l}\text { Hôpital de } \\
\text { Fourvière }\end{array}$ & 83 & 0 & - & - & - & 0 & $-\quad-$ & - & & Argant34 \\
\hline 47 & $\begin{array}{l}\text { Hôpital de } \\
\text { Fourvière }\end{array}$ & 424 & 0 & - & - & - & 0 & $-\quad-$ & - & & Argant34 \\
\hline 47 & $\begin{array}{l}\text { Hôpital de } \\
\text { Fourvière }\end{array}$ & 658 & I & ? & - & - & 0 & - - & - & I limb & Argant34 \\
\hline 12 & $\begin{array}{l}\text { Hôpital de } \\
\text { l'Antiquaille }\end{array}$ & 294 & 0 & - & - & - & 0 & $-\quad-$ & - & & Argant22 \\
\hline
\end{tabular}


Table Continued....

\begin{tabular}{|c|c|c|c|c|c|c|c|c|c|c|c|}
\hline $\mathbf{N}^{\circ}$ & Site & & Equids & & & & Dogs & & & Remarks & Source \\
\hline 73 & Hôtel de Cuzieu & 95 & 0 & - & - & - & 0 & - & - & & Argant 25 \\
\hline 73 & Hôtel de Cuzieu & 163 & 0 & - & - & - & 5 & ? & - & Young and adult gracil dogs & Argant25 \\
\hline 75 & La Boisse & 106 & 0 & - & - & - & 2 & - & $-\quad+$ & Canid in incineration & Silvino38 \\
\hline 50 & Place de la Bourse & 42 & 0 & - & - & - & 0 & - & - & & Arlaud39 \\
\hline 77 & $\begin{array}{l}\text { Place de la } \\
\text { République }\end{array}$ & 79 & 0 & - & - & - & 0 & - & - & & Arlaud39 \\
\hline 78 & Rue Bellecordière & 155 & 0 & - & - & - & 0 & - & - & & Argant3 \\
\hline 79 & $\begin{array}{l}\text { rue Colonel } \\
\text { Chambonnet }\end{array}$ & 209 & 0 & - & - & - & 0 & - & - & & Argant3 \\
\hline 79 & $\begin{array}{l}\text { rue Colonel } \\
\text { Chambonnet }\end{array}$ & 135 & 0 & - & - & - & 0 & - & - & & Argant3 \\
\hline 79 & $\begin{array}{l}\text { rue Colonel } \\
\text { Chambonnet }\end{array}$ & 50 & 0 & - & - & - & 0 & - & - & & Argant3 \\
\hline 79 & $\begin{array}{l}\text { rue Colonel } \\
\text { Chambonnet }\end{array}$ & 439 & 0 & - & - & - & I & ? & $?$ & & Argant3 \\
\hline 83 & $\begin{array}{l}\text { Théâtre des } \\
\text { Célestins }\end{array}$ & 179 & 0 & - & - & - & 4 & ? & $?$ & & Argant5 \\
\hline 83 & $\begin{array}{l}\text { Théâtre des } \\
\text { Célestins }\end{array}$ & 334 & 0 & - & - & - & I & ? & $?$ & & Argant5 \\
\hline 15 & Vénissieux & 143 & I & ? & - & ? & 4 & ? & - ? & 3 dogs & Forest24 \\
\hline
\end{tabular}

Table 3 Location of sites from Early empire - $2^{\text {nd }} c$. to Early middle age

\begin{tabular}{|c|c|c|c|c|c|c|c|c|c|c|c|c|}
\hline \multirow{2}{*}{\multicolumn{2}{|c|}{$\begin{array}{l}\mathbf{N}^{\circ} \quad \text { Site } \\
\text { Early empire }-2^{\text {nd }} c .\end{array}$}} & \multicolumn{5}{|c|}{ Equids } & \multicolumn{4}{|c|}{ Dogs } & \multirow[t]{2}{*}{ Remarks } & \multirow[t]{2}{*}{ Source } \\
\hline & & & & & & & & & & & & \\
\hline 1 & II-13 rue Roquette & 18 & 2 & $?$ & - & $?$ & 0 & - & - & - & & Argant [18] \\
\hline I & II-I3 rue Roquette & 44 & 6 & + & - & + & 0 & - & - & - & Cutmarks on humerus & Argant [18] \\
\hline 17 & 14, rue des Tuileries & 774 & 11 & + & + & - & 14 & - & - & $?$ & Sawed bones & Argant [40] \\
\hline 2 & BPNL & 544 & 133 & $?$ & $?$ & + & 33 & $?$ & $?$ & $?$ & & Forest [19] \\
\hline 27 & Rue Berthet/Cottin & 47 & 4 & $?$ & $?$ & $?$ & 1 & - & - & - & & Lalaï [13] \\
\hline 32 & Clos des Frères Maristes & 1008 & 0 & - & - & - & 3 & - & - & + & & Argant [14] \\
\hline 32 & Clos des Frères Maristes & 117 & 0 & - & - & - & 0 & - & - & - & & Argant [14] \\
\hline 46 & Genas & 2 & 0 & - & - & - & I & - & - & + & Dwarf hound (type Ib) & Argant [33] \\
\hline 47 & Hôpital de Fourvière & 194 & 0 & - & - & - & 1 & $?$ & - & $?$ & & Argant [34] \\
\hline 12 & Hôpital de l'Antiquaille & 1938 & 0 & - & - & - & 0 & - & - & - & Feast's wastes & Argant [22] \\
\hline 73 & Hôtel de Cuzieu & 45 & 0 & - & - & - & 0 & - & - & - & & Argant [25] \\
\hline 96 & Place Antonin Poncet & I & 0 & - & - & - & 1 & - & - & + & Dog's grave in little channel & unpublished \\
\hline 50 & Place de la Bourse & 91 & 0 & - & - & - & 4 & $?$ & $?$ & $?$ & & Arlaud [39] \\
\hline 98 & Place des Célestins & 102 & 0 & - & - & - & 0 & - & - & - & & Arlaud [39] \\
\hline 99 & Quai Arloing & 730 & 3 & - & + & + & 0 & - & - & - & Horse's patella in a child grave & Delaval [II] \\
\hline 100 & Quartier Saint-Pierre & I & 0 & - & - & - & 1 & - & - & + & Dog's grave with its bowl & Delaval [II] \\
\hline 100 & Quartier Saint-Pierre & I & 0 & - & - & - & 1 & - & + & - & $\begin{array}{l}\text { Dismembered dog, thrown on } \\
\text { the road side }\end{array}$ & Delaval [II] \\
\hline
\end{tabular}


Table Continued...

\begin{tabular}{|c|c|c|c|c|c|c|c|c|c|c|c|c|}
\hline \multirow{2}{*}{$\frac{\mathbf{N}^{\circ}}{100}$} & \multirow{2}{*}{$\begin{array}{l}\text { Site } \\
\text { Quartier Saint-Pierre }\end{array}$} & \multicolumn{5}{|c|}{ Equids } & \multicolumn{4}{|c|}{ Dogs } & \multirow{2}{*}{$\begin{array}{l}\text { Remarks } \\
\text { Mass grave }\end{array}$} & \multirow{2}{*}{$\begin{array}{l}\text { Source } \\
\text { Delaval [II] }\end{array}$} \\
\hline & & 5 & 5 & - & - & + & 0 & - & - & - & & \\
\hline 103 & rue du Chapeau Rouge & 1 & I & - & - & + & 0 & - & - & - & $\begin{array}{l}\text { Foal in the filling of a room of a } \\
\text { ceramic workshop. }\end{array}$ & unpublished \\
\hline 83 & Théâtre des Célestins & 263 & 0 & - & - & - & I & ? & $?$ & $?$ & & Argant [5] \\
\hline 83 & Théâtre des Célestins & 21 & 0 & - & - & - & 1 & $?$ & $?$ & $?$ & & Argant [5] \\
\hline 83 & Théâtre des Célestins & 23 & 0 & - & - & - & 0 & - & - & - & & Argant [5] \\
\hline 46 & Genas & 2 & I & - & - & + & 0 & - & - & - & Foal $A B G$ associated with calf & Argant [33] \\
\hline 83 & Théâtre des Célestins & 110 & 0 & - & - & - & 0 & - & - & - & & Argant [5] \\
\hline 53 & 19-21 rue Fossés de Trion & 8 & 0 & - & - & - & 0 & - & - & - & & Rémy [27] \\
\hline
\end{tabular}

\section{Late Empire}

5

$47 \quad$ Hôpital de Fourvière

73 Hôtel de Cuzieu

II4 Hôtel de Gadagne

II5 Parking Saint-Georges

$98 \quad$ Place des Célestins

78 Rue Bellecordière

83 Théâtre des Célestins

II6 7-II rue des Chartreux

$\begin{array}{llllllllll}199 & 0 & - & - & - & 2 & - & - & + & \text { Young dog in well } \\ 376 & 2 & - & - & + & 2 & ? & - & ? & \begin{array}{l}\text { Equids and dogs in well. } \\ \text { Pathological and gnawed dog }\end{array} \\ 658 & 0 & - & - & - & 4 & - & - & ? & \text { Small dog } \\ 37 & 0 & - & - & - & 1 & - & - & - & \\ 79 & 0 & - & - & - & 2 & ? & ? & + & \\ 1151 & 0 & - & - & - & 1 & ? & ? & ? & \\ 457 & 6 & ? & ? & ? & 2 & ? & ? & ? & \\ 100 & 3 & ? & ? & ? & 2 & ? & ? & ? & \\ 324 & 1 & ? & ? & ? & 0 & - & - & - & \\ 66 & 36 & - & + & + & 0 & - & - & - & \text { Sawed horses bones, exposition }\end{array}$

Argant [35]

Argant [35]

Argant [34]

Argant [25]

Argant [3]

Ayala [4I]

Arlaud [39]

Argant [3]

Argant [5]

Argant et al. [42]

\section{Late antiquity}

$\begin{array}{ll}58 & 4 \text { rue Saint-Didier } \\ 114 & \text { hôtel de Gadagne } \\ 115 & \text { Parking Saint-Georges } \\ 122 & \text { Place des Terreaux } \\ 123 & \text { rue du Père Chevrier } \\ 124 & \text { rue Mgr Lavarenne } \\ 125 & \text { Tramassac } \\ 15 & \text { Vénissieux }\end{array}$

$\begin{array}{lllllllll}57 & 19 & ? & - & + & 1 & + & - & - \\ 865 & 2 & ? & ? & ? & 0 & - & - & - \\ 574 & 11 & + & - & ? & 4 & ? & ? & ? \\ 412 & 3 & ? & ? & ? & 5 & ? & ? & ? \\ 94 & 4 & ? & ? & ? & 5 & ? & ? & ? \\ 764 & 0 & - & - & - & 0 & - & - & - \\ 8815 & 20 & + & ? & - & 43 & ? & ? & ? \\ 66 & 2 & ? & ? & ? & 4 & ? & ?\end{array}$

Cutmarks on equid vertebra?, elbow dislocation on dog

Donkey and horse
Argant [36]

Argant [3]

Ayala [4I]

Arlaud [39]

Blaizot et al. [43]

Argant [44]

Arbogast [6]

Forest [24]

Erratic distribution of equids, $\operatorname{dog} A B G$

Argant [36]

Ayala et al. [45]

Ferber [46]

Argant [3]

Arlaud [39] 


\section{History of the horse (Equidae)}

Horse remains occur in zooarchaeological assemblages continuously from the early Bronze Age to the second Iron Age (Figure 4). During the Roman period, for about a century and notably in the town centre, their bones are only recovered from a very limited number of contexts, but gradually become more frequent again from the 2nd c. A.D.

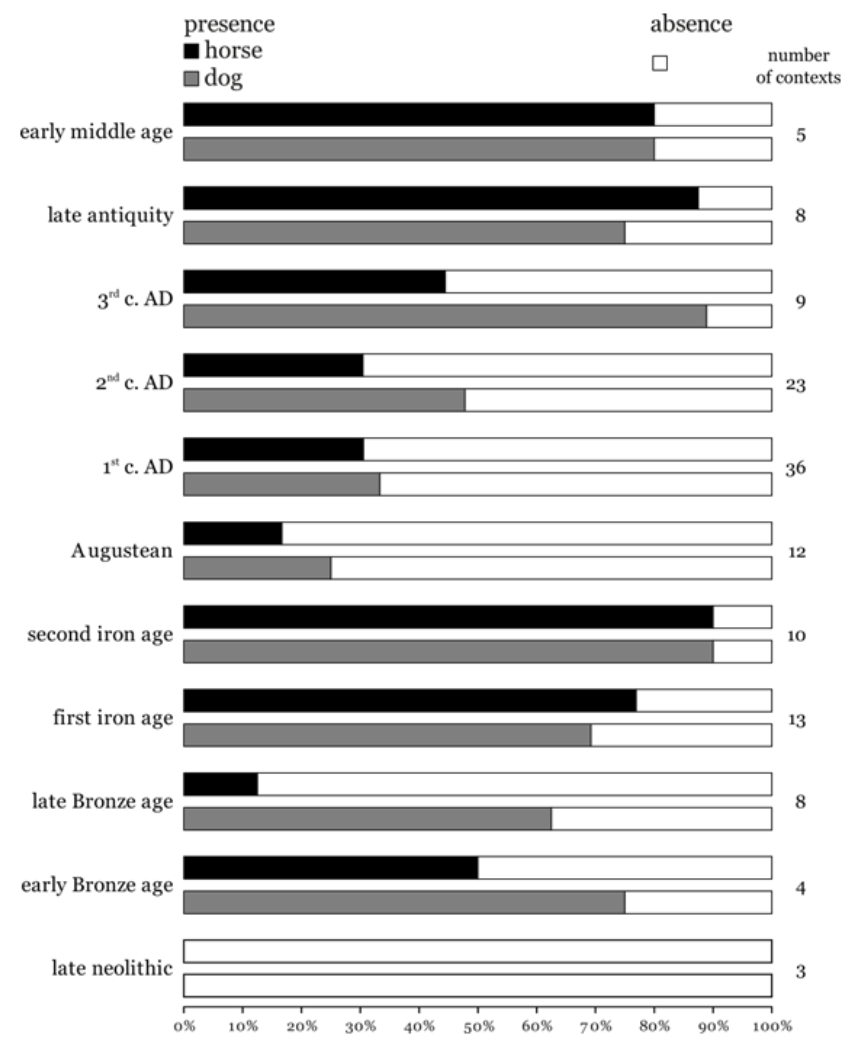

Figure 4 Proportion of sites where horse or dog are represented for each chronological layer in Lyon and around (Table I).

During the first Iron Age, evidence for butchery on equid bones is rare, though a thoracic vertebra from rue du docteur Horand displays clear cut marks. ${ }^{7}$ In addition, pathologies are also witnessed on some horse bones in this period, indicating their difficult living conditions at that time (Figure 5). In the second Iron Age, horse consumption is more evident, though evidence that horses were also exploited in other ways is also detectable. On some sites, such as rue Roquette in Vaise, cut marks have been observed on meat-baring parts of the skeleton, as well as patterns of bone breakage similar to that seen on cattle in particular. On the top of the hill of Fourvière, many complete horse bones were discovered in a ditch at Verbe Incarné in association with a high number of pig bones, remains which were interpreted as the debris from a large feast, ${ }^{8}$ though here it is uncertain whether horse flesh was consumed. A similar pattern was also recorded at îlot Cordier, though this time horse bones were predominantly found in association with cattle remains and were butchered in a similar manner, suggesting that horse consumption had taken place. ${ }^{9}$

In the necropolis of Chais Beaucairois, four tombs contained the bones of both humans and domestic mammals. Among them, elderly stallions (more than 10 years old) were found lying on their side in the funeral chamber. ${ }^{10}$ These aged animals showed pathologies associated with the carrying of heavy loads and we can suppose that these were used as mounts, perhaps belonging to the deceased. Alternatively, they may have been chosen from animals unfit for service, as a symbolic gesture, in a context where they were of great value.

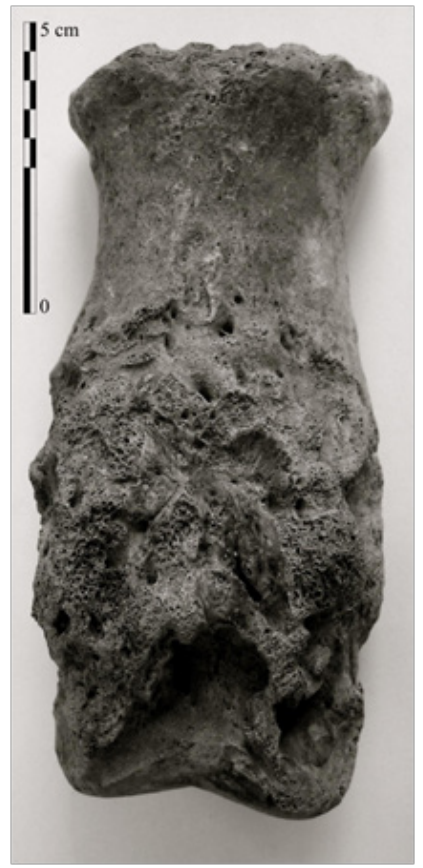

Figure 5 I4 rue des Tuileries, First Iron Age. First and second horse phalanx fused together following bacterial infection?

In the initial period of the Roman colony, horse bones are lacking from most sites, especially in the centre of the city (Figure 6). At the same time, however, the first evidence for knackery is also identified from the remains of complete long bones plus some associated bone groups discovered, notably in ditches located around the necropolis, outside of the compendium in the Vaise suburbs. During the 2nd c. A.D., evidence for horse consumption returns, once again in the form of fractured bones which display cut marks from meat-baring parts of the skeleton. However, this evidence is still restricted to suburban areas, whereas horse bones remain completely absent from within the colony. Occurrences of horse butchery in funerary areas is also fairly common from this phase, along with more rarely horses buried in pits, such as at boulevard périphérique nord de Lyon. At the quartier Saint-Pierre, an exceptional burial of humans and horses were found together in a pit along a suburban street. ${ }^{11}$

The occurrence of equid bones amongst craft-working waste became more common during the 3rd c. A.D., whilst in the early Roman period only cattle bones were used for this purpose. This may indirectly indicate evidence for horse consumption if the retrieval of long bones for craft-workers was integrated with the butchering process. On the site of rue des Chartreux, bone-working waste was found deposited in a rectangular ditch which surrounded an empty 'inhumation' pit. Within the ditch, disarticulated human skulls and long bones were identified along with a very poorly preserved horse skull, a lion tibia and a bear molar (Figure 7). The interpretation of the feature, possibly a structure, is difficult to determine. It may have been a monument erected to commemorate an event, perhaps associated with the amphitheatre, which may explain the association of people and wild animals in this context, or perhaps a trophy erected following one of the battles of 197 between the armies of the rival emperors Albinus and Septimus Severus which took place around Lyon. ${ }^{12}$ 

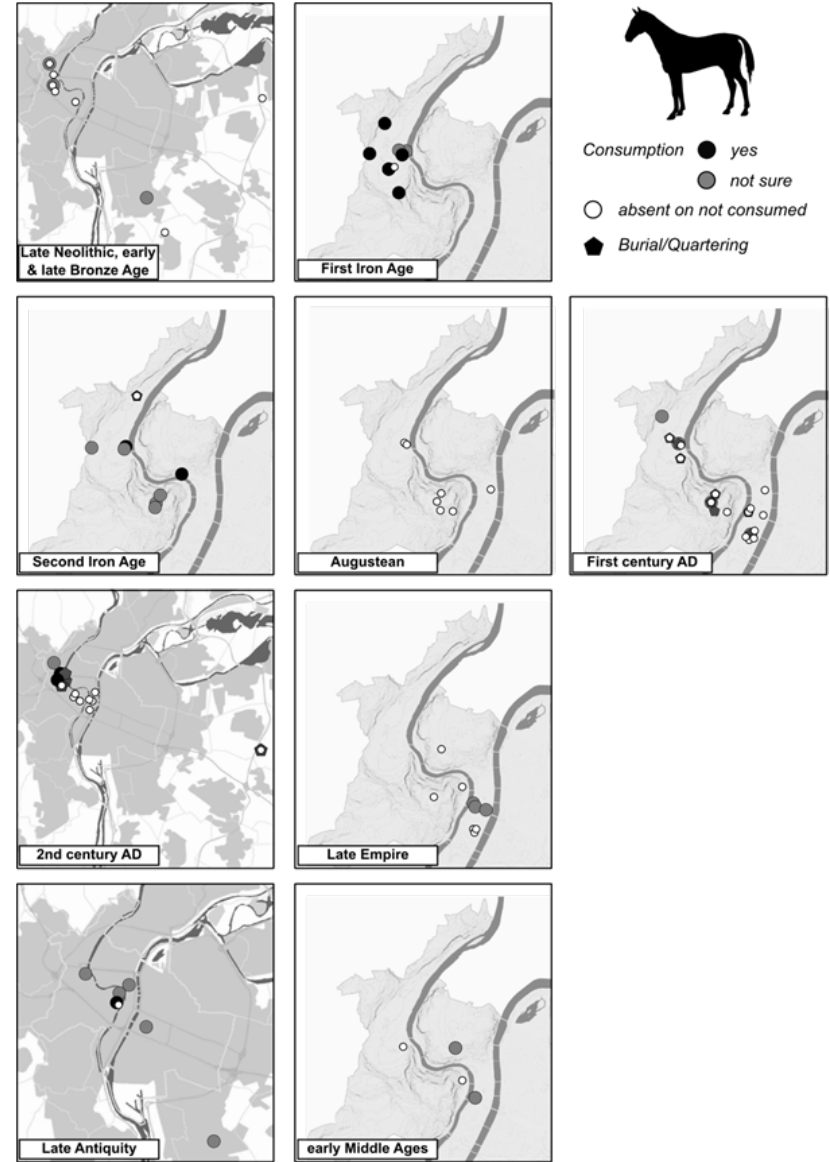

Figure 6 Maps of horse presence, consumption and burial, by chronological layer (based on table I).

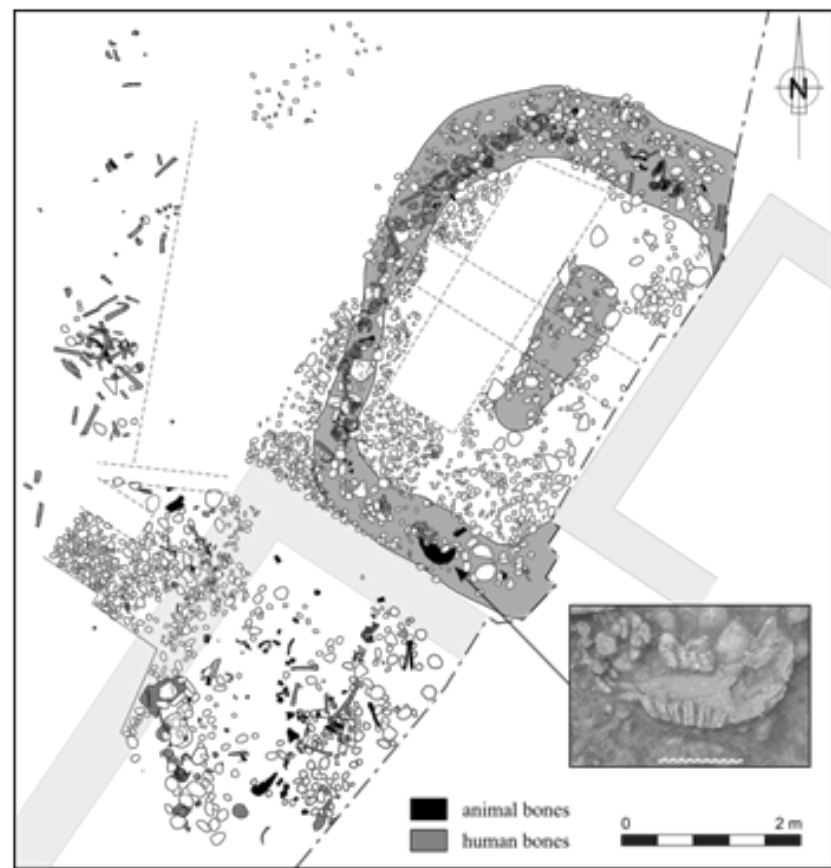

Figure 7 7-II rue des Chartreux. Plan of the third century ditch with human and animal bones exposed. The picture shows the horse skull. Only the upper teeth were preserved, with the mandible.
By the end of Roman period, horse bones continued to be recovered in very small amount from the slaughterhouses and urban butcheries at Tramassac, perhaps indicating that the consumption of horse meat also continued, though direct evidence is lacking. ${ }^{6}$ Similarly, in the Early Middle Ages, the consumption of horse meat is suspected from remains on some sites, whilst only a few centuries later, it became very common in the countryside around Lyon, especially on agriculturallypoor land on the Dombes plateau to the north-east.

\section{History of the dog (Canis familiaris)}

Canid bones have been recovered from the majority of sites in Lyon dating from the early Bronze Age and, similar to horses, the Roman period appears to be an exception in that continuum (Figure 4). It is difficult to identify evidence for dog consumption from Bronze Age sites, notwithstanding the possibility that some bones from that period might have derived from wolves. Contrastingly, cynophagy is frequently mentioned in site reports dating to the first Iron Age. At Rue Roquette, for example, scapula and os coxae bones exhibited clear evidence for cut marks, suggesting that dog meat had been consumed. On other sites, as at rue du Docteur Horand and rue Berthet, butchered phalanx and metapodials suggest the exploitation of skins, whilst the first evidence for the inhumation of a dog is also testified at rue Berthet. ${ }^{13}$

During the second Iron Age, evidence for dog consumption continues. For example, at Saint-Vincent, clear and deep cut marks appear on dog tibiae. Other specimens were associated with inhumation burials of the Chais beaucairois ${ }^{14}$ (Figure 8 ). At this site, two matching mandibles from a puppy were placed on top of a funerary vessel, possibly as a food offering. Notably, a similar deposit was identified at the necropolis of Lamadelaine in Luxembourg, where Méniel noted the presence of puppy and chicken bones placed on top of a pot as possible food items..$^{15}$
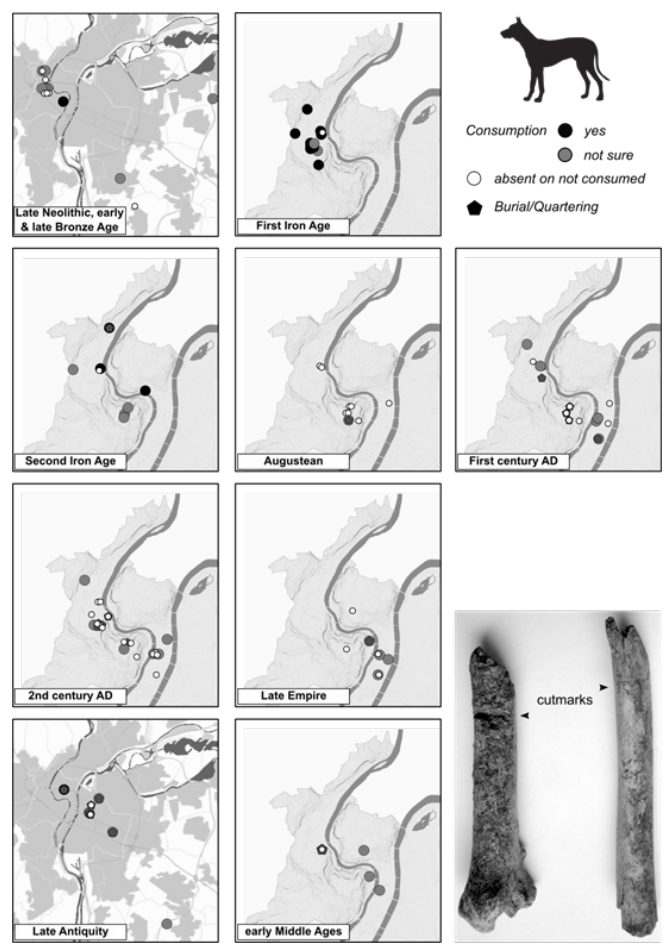

Figure 8 Maps of dog presence, consumption and burial, by chronological layer (based on table I). Example of cutmark on dog tibias from Saint-Vincent. 
During the early Roman period, evidence for canids scavenging on carcass parts is regularly observed from gnaw marks on bones, suggesting that dogs were common on the streets and around rubbish dumps. However, evidence for dog consumption disappears during this period (Figure 8), whilst dog burials become more prolific within the city. A more exceptional find includes the identification of dog bones amongst burned offerings in a funeral pyre at the villa of $\mathrm{La}$ Boisse. There is also evidence for small dog breeds in the Roman town, for example at Verbe Incarné, whilst evidence for dwarf hounds have been found close to the town at Rue Saint-Didier and at nearby rural settlements such as Genas. Similarly, in the 2nd c. A.D., no evidence for the consumption of dog meat has been identified, though dog burials continue to be common. However, some remains demonstrate that individual dogs may have been treated quite differently by people in the town. One dog, with poorly-healed fractures, had been skinned before being disposed of along a street in the quartier Saint-Pierre. ${ }^{11}$ In contrast, on the same site, another individual was carefully buried with a vessel, which may have been the dog's bowl. On this specimen, the right humerus demonstrated a healed fracture, though this appeared to have mended well, perhaps with the help of a thoughtful master. ${ }^{1}$

During Late Antiquity (mid-4th c. A.D.), in the suburban Vaise area, at rue Saint-Didier, an adult ulna shows cut marks on the proximal end, perhaps indicating that the dog had been consumed. At Hôtel de Gadagne, a dog was found partially burned and deposited with coins in the foundations of a hypocaust, just prior to being sealed by a concrete slab. ${ }^{16}$ By the Early Middle Ages, some instances of dog burial continue, whilst isolated bones may be more ephemeral evidence for dog consumption, though this remains to be proven.

\section{Conclusion}

To conclude, evidence that dogs and horses were eaten before the establishment of the Roman colony at Lyon is found at a number of sites. However, a Roman taboo ${ }^{17}$ over the consumption of dogs and horses appears to have been exercised from the beginning of that period (Figure 9). At the same time, a diversification of dog breeds occurred when they also began to appear in a range of ritual practices and some may have been cared for. Contrastingly, evidence for stray dogs scavenging in the town streets also becomes more common, with a number exhibiting pathologies suggesting that they had been poorly treated.

$\checkmark$ eaten since first iron age - at Before $\checkmark$ appear timidly at the
least ;
$\checkmark$ use of dog skin
$\checkmark$ scavenger
$\checkmark$ offering in tombs
$\checkmark$ buried ; skinned by of Bronze Age
$\checkmark$ bets, breeds diversification with people
$\checkmark$ implicated in rituals
$\checkmark$ buried
$\checkmark$ eaten ??

Figure 9 Synthesis of dog's and horse's status in Lyon from Neolithic to Early Middle Ages showing the influence of the Roman period.
For horses and other equids, a different history is evident. Horses were eaten by the Gauls, but also buried alongside people and other domestic species. If their consumption stopped strictly with the arrival of the Romans, it appears to have started once more from the middle of the 2nd c. A.D. At this time, horse bones were also exploited for craft-working and raw resources may have been supplied through knackers. And, since they were not eaten, their carcasses appear to have been scattered in the suburbs and in the neighbourhood of the necropolis. ${ }^{47,48}$

\section{Acknowledgements}

I am grateful to Martyn Allen who helped me with the composition of this article, after I was unable to attend the 2014 Roman Archaeology Conference session on which it is based, and also to Rowan Lacey (Éveha) for his helpful review of my English.

\section{Conflict of interest}

Author declares there is no conflict of interest.

\section{References}

1. Carrara S, Maza G, Rottier S. L'agglomération urbaine de Lyon-Vaise (Rhône) à la fin du VIe s. et au Ve s. av. J.-C.: bilan des découvertes. In: Buchsenschultz O, et al. editor. L'âge du Fer dans la boucle de la Loire, Les Gaulois sont dans la ville. France; 2009. p. 207-235.

2. Maza G. Débats récents sur l'interprétation de l'établissement gaulois de la rue du Souvenir à Lyon-Vaise: une résidence aristocratique gauloise ? Nouvelles hypothèses. In: Lemaître S, Vallet BC, Hommage, Desbat A, editors. Autun. France; 2015. p. 87-98.

3. Argant T. L'Alimentation d'origine animale à Lyon des origines au XXe siècle. Université Lumière Lyon 2, France; 2001.

4. Columeau P. L'Animal pour l'Homme. Recherches sur l'alimentation carnée dans le sud de la France du Néolithique au Moyen-Age d'après les vestiges osseux. Université de Provence, France; 1991.

5. Argant T. Théâtre des Célestins : rapport d'étude de la faune du troièsième dessous. Service Archéologique de la Ville de Lyon, France; 2003.

6. Arbogast RM. Les fouilles de l'îlot Tramassac. In: Arlaud C, editor. Document d'Archéologie Rhône-Alpes, France; 1994. p. 117-133.

7. Argant T. Approche archéozoologique du premier âge du Fer de la plaine de Vaise à Lyon (Rhône). Mémoire de DEA. Université Lumière Lyon 2, France; 1996.

8. Krausz S. La faune de l'Hôpital Sainte-Croix de Lyon. Parcourir les collections. 1990;47(1):97-102.

9. Jacquet PO, Franc D, Lalaï G, et al. Le site de l'îlot Cordier : un exemple de fouille de fossé de La Tène D à Lyon-Vaise,» in De l'âge du Bronze à l'âge du Fer en France et en Europe occidentale (Xe-XIIe siècle av. J.C.). la moyenne vallée du Rhône aux âges du Fer, Saint-Romain-en-Gal, France; 2009. p. 83-96.

10. Argant T. Cortèges d'animaux dans des tombes sous tumulus de La Tène à Lyon (Rhône, France). RAE. 2014;63:433-449.

11. Delaval E, Bellon C, Chastel J, et al. Vaise, un quartier de Lyon antique. OpenEdition Book, France; 1995. p. 291.

12. Argant T. Une autre sorte de peau: le lion de lyon. In: Lemaître S, Vallet BC, Hommage, Desbat A, editors. Autun Editions Mergoil, France; 2015. p. 139-143.

13. Lalaï D. Les restes fauniques. In: Bellon C, Nourrissat S, editors. Rapport de fouille: Lyon 9e 24-34 rues Sergent Michel Berthet - Saint-Pierre de Vaise Berthet II, (Inrap, Lyon), 2005;119-128.

${ }^{1}$ Ibid 65. 
14. Argant T. Clos des frères Maristes (Lyon 05, Rhône). Rapport d'étude préliminaire de la faune. Archeodunum. France; 2014a.

15. Méniel P. Les restes animaux du site protohistorique de Gorge de Loup à Lyon 09. Compiègne. France; 1988.

16. Becker C, Kontis IP, Guerraz SS, et al. Archéologie et histoire au coeur d'un projet patrimonial à Lyon Document d'Archéologie Rhône-Alpes. France; 2006.

17. Lauwerier RCGM. Eating horsemeat: the evidence in the Roman Netherlands. Archaeofauna. 1999;8:101-113.

18. Argant T. 11-13 rue Roquette (Lyon 09, Rhône). Rapport d'étude de la faune, Archeodunum. France; 2013.

19. Forest V. Boulevard périphérique nord de Lyon: Archéozoologie. Rapport final. France; 1996a.

20. Méniel P. La question du sacrifice animal dans les rites funéraires en Gaule Belgique. Revue archéologique de Picardie. 1998;1(1):245-251.

21. Argant T. Etude de la faune des niveaux protohistoriques de SaintVincent. Service Archéologique de la Ville de Lyon. France; 2007.

22. Argant T. Hôpital de l'Antiquaille (Lyon 05, Rhône). Rapport d'étude de la faune. Archeodunum. France; 2012b.

23. Forest V. Les Hernières Meyzieu (69). Rapport d'étude de la faune. France; 1994a.

24. Forest V. Etude des ossements et dents d'origine animale. In : Joly L, Taras M, editors. Opération "ZAC Du Vieux Bourg" à Vénissieux (Rhône). Rapport de fouilles place de La Paix (Afan, Lyon). 1994b.

25. Argant T. Hôtel de Cuzieu (Lyon 02, Rhône). Rapport d'étude de la faune, Service Archéologique de la Ville de Lyon. France; 2008a.

26. Poulain T. Faune hallstattienne de Sérézin du Rhône. Hauts Moments d'un Groupuscule Archéologique, Comm 3 APPAS. 1963;43-48.

27. Lalaï D. Les restes fauniques. In: Rémy AC, editor. Rapport de fouilles archéologiques au 19-21, rue des fossés de Trion (Lyon 05, Rhône) Inrap Rhône-Alpes/Auvergne. France; 2003.

28. Forest V. Etude archéozoologique au 65 rue du Souvenir. France; 1999.

29. Goudineau C. Aux origines de Lyon. Document d'Archéologie RhôneAlpes, Open Edition Books, France; 1989. p. 128.

30. Argant T. Rapport d'étude de la faune antique. Éveha Décines-Charpieu. France; 2014b.

31. Forest V. Étude de faune. In: Desbat A, editor. Rapport sur les sondages effectués en 1996 dans l'édifice dit "sanctuaire de Cybèle". France; $1996 \mathrm{~b}$

32. Forest V. Étude archéozoologique du site de "Cybèle" (Lyon, 05): la faune du sondage F2 (40 av. JC. - 10 ap. JC.). In: Desbat A, editors Lyon : du site gaulois à la fondation coloniale. évolution du milieu et des échanges. Recherches sur les débuts de la romanisation à Lyon (milieu IIe siècle / fin Ier siècle av. JC.): Rapport Intermédiaire, PCR 1999-2001, Lyon; 2000.
33. Argant T. Genas-ZAC G Sud (Rhône). Rapport d'étude de la faune (Archeodunum, Chaponnay). 2012a.

34. Argant T. Lyon 05 - Hôpital de Fourvière (Lyon 05, Rhône). Rapport d'étude de la faune, Archeodunum, Chaponnay. France; 2011.

35. Argant T. Rapport d'étude de la faune. Éveha Décines-Charpieu. France; $2014 c$.

36. Argant T. 4 rue Saint-Didier/13 rue des Nouvelles Maisons (Lyon 09, Rhône). Rapport d'étude de la faune, Archeodunum. France; 2012c.

37. Schmitt A, Monin M, Bertrand E, et al. Un ensemble funéraire du HautEmpire le long de la voie de l'oécan (Lyon 9e). RAE. 2012;59:287-351.

38. Silvino T, Blaizot F, Maza G. La villa des Vernes à La Boisse (Ain): contribution des fouilles récentes à la compréhension de l'évolution d'un établissement rural antique et de son espace funéraire. $R A E$. 2011;60:217-290.

39. Arlaud C. Lyon, les dessous de la Presqu'île: Bourse-RépubliqueCélestins-Terreaux. Sites Lyon Parc Auto, Document d'Archéologie Rhône-Alpes, France; 2000. p. 280.

40. Argant T. 14, rue des Tuileries (Lyon 09, Rhône). Rapport d'étude de la faune, Archeodunum, Chaponnay. France; 2008b.

41. Ayala G. La fouille du parc Saint-Georges: histoire d'un bord de Saône. Rapport final d'opération. Inrap. France; 2005.

42. Argant T, Argant C, Baradat A, et al. Rapport d'Opération d'Archéologie Préventive au 7-9-11 rue des Chartreux. Service Archéologique de la Ville de Lyon. France; 2007.

43. Blaizot F, Argant T, Bonnet C, et al. Archéologie d'un espace suburbain de Lyon à l'époque romaine. Le mobilier et les structures dispersées: témoignages de quelles activités? Gallia. 2010;67:32-36.

44. Argant T. Rue Monseigneur Lavarenne (Lyon-05) rapport d'étude de la faune. Service Archéologique de la Ville de Lyon, France; 2005.

45. Ayala G, Blaizot F, Horry A, et al. Un habitat et des sépultures du haut Moyen Age sur les pentes de la Croix-Rousse à Lyon. Archéologie Médiévt. 2003;33:33-62.

46. Ferber E. Rapport d'opération archéologique à Décines-Charpieu (Rhône). Le Montout OL land tranche 1, Inrap Rhône-Alpes. France; 2012.

47. Lalaï D. Étude de la faune. In : Vicard T, editors. Rapport final de fouille: le Grand Bazar, Place des Cordeliers (Lyon 02, Rhône), Inrap RhôneAlpes/Auvergne, France; 2006. p. 118-135.

48. Poux M, Savay-Guerraz H. Lyon avant Lugdunum. Infolio, Gollion. Switzerland; 2003. p. 152. 